\title{
RET Inhibitor LOXO-292
}

National Cancer Institute

\section{Source}

National Cancer Institute. RET Inhibitor LOXO-292. NCI Thesaurus. Code C134987.

An orally bioavailable selective inhibitor of wild-type, mutant and fusion products involving the proto-oncogene receptor tyrosine kinase rearranged during transfection (RET), with potential antineoplastic activity. Upon oral administration, LOXO-292 selectively binds to and targets various RET mutants and RET -containing fusion products. This results in an inhibition of cell growth of tumors cells that exhibit increased RET activity. RET overexpression, activating mutations, and fusions result in the upregulation and/or overactivation of RET tyrosine kinase activity in various cancer cell types; dysregulation of RET activity plays a key role in the development and progression of these cancers. 